\title{
COMMENTARY
}

\section{Selectivity to amyloid- $\beta$ precursor protein cleavage provides hope against Alzheimer's}

\author{
Taisuke Tomita*1 and Philip C Wong*2 \\ See related research by Basi et al., http://alzres.com/content/2/6/36
}

\begin{abstract}
Toward development of a safe and effective treatment for Alzheimer's disease, Elan Pharmaceuticals reported a novel $\gamma$-secretase inhibitor that specifically targets the cleavage of amyloid- $\beta$ precursor protein, opening the way to design of substrate-specific $\gamma$-secretase inhibitors that would reduce the amyloid burden without significant adverse events.
\end{abstract}

As the population in most industrialized nations ages, the development of disease-modifying agents against Alzheimer's disease (AD), the most common cause of dementia in the elderly, is one of the most important unmet medical needs in the world. Because of strong experimental support for amyloid- $\beta$ (A $\beta$ ), a small peptide derived from the sequential cleavage of amyloid- $\beta$ precursor protein (APP) by BACE1 and $\gamma$-secretase, as the principle culprit in this devastating neurodegenerative disease, investigators focused efforts to develop compounds designed to inhibit the activity of $\gamma$-secretase in order to attenuate $\beta$-amyloidosis as a potential therapy for AD [1]. However, Eli Lilly and Company announced last year that it was halting the development of semagacestat, a first-in-man $\gamma$-secretase inhibitor [2,3]. Two ongoing phase III studies showed that treatments using semagacestat were associated with worsening of clinical measures of cognition and the ability to perform activities of daily living, as well as an increased risk of skin cancer. The exact molecular mechanisms underlying these adverse events remain unclear. However, semagacestat mechanistically inhibits not only $\gamma$-secretase to prevent

\footnotetext{
*Correspondence: taisuke@mol.f.u-tokyo.ac.jp; wong@jhmi.edu 'Department of Neuropathology and Neuroscience, Graduate School of Pharmaceutical Science, The University of Tokyo, 7-3-1 Hongo, Bunkyo, Tokyo 113-0033, Japan

2Departments of Pathology and Neuroscience, The Johns Hopkins University School of Medicine, 558 Ross Research Building, 720 Rutland Avenue, Baltimore, MD 21205, USA
}

A $\beta$ production but also Notch, one of the most important physiological substrates for $\gamma$-secretase in vivo [4]; genetic and pharmacological studies in mice supported the notion that the inhibition of $\gamma$-secretase caused toxicities by impacting Notch signaling. The skin cancer risk was predicted from animal studies in which $\gamma$ secretase/Notch signaling was globally attenuated $[5,6]$. Thus, development of $\gamma$-secretase inhibitors/modulators that specifically inhibit the production of $A \beta$ without influencing Notch activity is now necessary or mandatory as a treatment strategy for $\mathrm{AD}[2,7]$.

In a recent paper, Basi and co-workers at Elan Pharmaceuticals report a preclinical study of two novel sulfonamide-type small molecules, ELN318463 and ELN475516 [8]. These compounds showed predominant inhibitory potency against $A \beta$ production over Notch signaling in vitro, suggesting that both molecules selectively inhibit APP cleavage by $\gamma$-secretase. Moreover, subchronic oral administration of one compound, ELN475516, significantly reduced $A \beta$ levels in brains of APP transgenic as well as wild-type mice. Importantly, treatment with ELN475516 did not show any inhibition of the expression of Notch target genes at the peripheral target, and no overt systemic toxicity was observed. These data indicate that it is possible to develop compounds exhibiting APP-selective $\gamma$-secretase inhibition in vivo. Furthermore, Basi and colleagues revealed an intriguing finding regarding the molecular mechanism whereby these compounds confer APP selectivity by employing a chemical biology approach: only in the presence of the recombinant APP substrate were ELN compounds able to displace the active site isostere that directly targets both catalytic aspartates in PS1. In contrast, a non-selective classical inhibitor displaced the active site isostere from PS1 irrespective of the presence of the substrate, indicating that these ELN compounds selectively target the APP-cleaving PS1 conformation induced by the substrate. These data, therefore, suggest that APP-selective inhibition is feasible by developing small molecules that target the non-catalytic domains of $\gamma$-secretase. Supporting this notion, it has been reported that the substrate recognition mechanism in the 
$\gamma$-secretase is enzymatically distinct from the catalytic site, and that the substrate interaction induces an allosteric conformational change in the PS1 molecule [9]. Interestingly, Basi and colleagues have reported previously that this class of compounds, known as 'Notchsparing $\gamma$-secretase inhibitors' selectively inhibits PS1containing over PS2-containing $\gamma$-secretase [10]. Nevertheless, identification of the molecular target and the precise binding site of ELN compounds may provide important progress towards the rational development of APP-selective $\gamma$-secretase inhibitors. Future structural analysis of this atypical membrane-embedded protease would shed light on the mechanism of APP selectivity. In addition, molecular analysis of such selectivity of ELN compounds versus other $\gamma$-secretase substrates might further clarify the mechanism-based advantage of these compounds. Importantly, recent genetic and chemical biology approaches revealed that there are several possible druggable target molecules within the $\gamma$-secretase complex and the substrate [11-13]. In addition, after intensive efforts several laboratories have recently developed $\gamma$-secretase modulators that selectively inhibit A $\beta 42$ production [14-16]. Combination approaches against several targets may be effective for reducing the levels of $\mathrm{A} \beta$ without inhibiting Notch in vivo [17]. In conclusion, Basi and colleagues provide strong evidence that it is possible to develop small APP-selective $\gamma$-secretase inhibitors that 'spare' Notch. Understanding the precise molecular mechanism whereby ELN compounds modulate the $\gamma$-secretase activity would pave the way to develop a potentially safe and effective compound to attenuate $\beta$-amyloidosis in $\mathrm{AD}$.

\section{Abbreviations}

$A \beta$, amyloid- $\beta ; A D$, Alzheimer's disease; APP, amyloid- $\beta$ precursor protein.

\section{Competing interests}

The authors declare that they have no competing interests.

Published: 11 March 2011

\section{References}

1. De Strooper B, Vassar R, Golde T: The secretases: enzymes with therapeutic potential in Alzheimer disease. Nat Rev Neurol 2010, 6:99-107.

2. Extance A: Alzheimer's failure raises questions about disease-modifying strategies. Nat Rev Drug Discov 2010, 9:749-751

3. Eli Lilly and Company: Lilly Halts Development of Semagacestat for
Alzheimer's Disease Based on Preliminary Results of Phase III Clinical Trials [http://newsroom.lilly.com/releasedetail.cfm?releaseid=499794]

4. Kopan R, llagan MX: The canonical Notch signaling pathway: unfolding the activation mechanism. Cell 2009, 137:216-233.

5. Li T, Wen H, Brayton C, Laird FM, Ma G, Peng S, Placanica L, Wu TC, Crain BJ, Price DL, Eberhart CG, Wong PC: $\gamma$-secretase attenuates amyloid burden and limits mechanism-based liabilities. J Neurosci 2007, 27:10849-10859.

6. Nicolas M, Wolfer A, Raj K, Kummer JA, Mill P, van Noort M, Hui CC, Clevers H, Dotto GP, Radtke F: Notch1 functions as a tumor suppressor in mouse skin. Nat Genet 2003, 33:416-421

7. Imbimbo BP, Panza F, Frisardi V, Solfrizzi V, D'Onofrio G, Logroscino G, Seripa D, Pilotto A: Therapeutic intervention for Alzheimer's disease with $\gamma$-secretase inhibitors: still a viable option? Expert Opin Investig Drugs 2011, 20:325-341.

8. Basi GS, Hemphill S, Brigham EF, Liao A, Aubele DL, Baker J, Barbour R, Bova M, Chen XH, Dappen MS, Eichenbaum T, Goldbach E, Hawkinson J, LawlerHerbold R, Hu K, Hui T, Jagodzinski JJ, Keim PS, Kholodenko D, Latimer LH, Lee M, Marugg J, Mattson MN, McCauley S, Miller JL, Motter R, Mutter L, Neitzel $M L, N i$, Nguyen L, et al.: Amyloid precursor protein selective gammasecretase inhibitors for treatment of Alzheimer's disease. Alzheimers Res Ther 2010, 2:36.

9. Uemura K, Farner KC, Hashimoto T, Nasser-Ghodsi N, Wolfe MS, Koo EH, Hyman BT, Berezovska O: Substrate docking to $\gamma$-secretase allows access of $\gamma$-secretase modulators to an allosteric site. Nat Commun 2010, 1:130.

10. Zhao B, Yu M, Neitzel M, Marugg J, Jagodzinski J, Lee M, Hu K, Schenk D, Yednock T, Basi G: Identification of $\gamma$-secretase inhibitor potency determinants on presenilin. J Biol Chem 2008, 283:2927-2938.

11. De Strooper B, Annaert W: Novel research horizons for presenilins and gamma-secretases in cell biology and disease. Annu Rev Cell Dev Biol 2010, 26:235-260.

12. He G, Luo W, Li P, Remmers C, Netzer WJ, Hendrick J, Bettayeb K, Flajolet M, Gorelick F, Wennogle LP, Greengard P: $\gamma$-secretase activating protein is a therapeutic target for Alzheimer's disease. Nature 2010, 467:95-98.

13. Tian Y, Bassit B, Chau D, Li YM: An APP inhibitory domain containing the Flemish mutation residue modulates gamma-secretase activity for Abeta production. Nat Struct Mol Biol 2010, 17:151-158.

14. Kukar TL, Ladd TB, Bann MA, Fraering PC, Narlawar R, Maharvi GM, Healy B, Chapman R, Welzel AT, Price RW, Moore B, Rangachari V, Cusack B, Eriksen J, Jansen-West K, Verbeeck C, Yager D, Eckman C, Ye W, Sagi S, Cottrell BA, Torpey J, Rosenberry TL, Fauq A, Wolfe MS, Schmidt B, Walsh DM, Koo EH, Golde TE: Substrate-targeting $\gamma$-secretase modulators. Nature 2008, 453:925-929.

15. Kounnas MZ, Danks AM, Cheng S, Tyree C, Ackerman E, Zhang X, Ahn K, Nguyen P, Comer D, Mao L, Yu C, Pleynet D, Digregorio PJ, Velicelebi G, Stauderman KA, Comer WT, Mobley WC, Li YM, Sisodia SS, Tanzi RE, Wagner SL: Modulation of gamma-secretase reduces beta-amyloid deposition in a transgenic mouse model of Alzheimer's disease. Neuron 2010, 67:769-780.

16. Oehlrich D, Berthelot DJ, Gijsen $H J$ : $\gamma$-Secretase modulators as potential disease modifying anti-Alzheimer's drugs. J Med Chem 2011, 54:669-698.

17. Chow VW, Savonenko AV, Melnikova T, Kim H, Price DL, Li T, Wong PC: Modeling an anti-amyloid combination therapy for Alzheimer's disease. SciTrans/ Med 2010, 2:1-11.

doi:10.1186/alzrt66

Cite this article as: Tomita T, Wong PC: Selectivity to amyloid- $\beta$ precursor protein cleavage provides hope against Alzheimer's. Alzheimer's Research \& Therapy 2011, 3:7. 